\title{
Distortions in the Nigerian Economy and the Roadmap to Vision 2020: Lessons from Past Development Strategies
}

\author{
Enobong C. Umobong ${ }^{1}$, Usenobong F. Akpan² \\ ${ }^{(1,2)}$ Department of Economics, Faculty of Social Sciences, University of Uyo, Nigeria
}

\begin{abstract}
It is generally agreed that the existence of government in an economy is to promote societal welfare. In order to properly organize and manage the use of resources to achieve desired goals and objectives, governments normally initiate economic frameworks, blueprints, roadmaps or plans which guide and coordinate economic activities within the economy. Thus, between 1960 to date, Nigeria has initiated several plans, frameworks, policies and strategies which, though well intended, have not significantly met the aspirations of her citizens. Presently, the desire of the country is to be among the top 20 economies in the world by the year 2020. The major concern of this paper is that since the present distortions in the Nigerian economy which the Vision 20:2020 seeks to address do not exist in historical vacuum, a re-assessment of the forces that held back Nigeria in the past is essential. Thus the paper attempts an evaluation of the various distortions that have impeded the efficacy of Nigeria's previous development strategies. Ensuing, we take a review of the various (major) economic strategies designed and adopted in the country till date. The paper identifies instability of the roadmaps - a fallout of the spirit to always do something new, frequent change of operators of the roadmap, reducing development to politics, poor implementation, non-implementation or outright sabotage, lack of good leadership, among others, as some of the factors that have kept us dancing in a vicious cycle of backwardness. In view of these, we articulate the challenges and prospects of achieving the Vision 20:2020.
\end{abstract}

Key Words: Nigeria, Development, Roadmap, Vision 20:2020

\section{Introduction}

The struggle to accelerate the pace of socio-economic development in Nigeria is a daunting challenge which dates back to the colonial days, with the launching of the famous "Ten-year Plan of Development and Welfare" for Nigeria by the colonial administration (Akpakpan, 2004). Although very minimal progress (except in the building of few schools) could be ascribed to this period ${ }^{1}$, it provided the springboard for further economic reforms and 'planning' of the Nigerian economy. The underlying consensus was (and still is) that the existence of government in an economy is to promote societal welfare. Economic policies represent a set of contract between the government and the various socio-economic groups in the society. A social charter or contract is said to be implied as the people (citizens or principal) "surrender" their sovereignty and collective resources to a group of other people (governments or agents), who in turn make policies and deployed the available resources of the state to ensure the common good. In order to properly organized and managed the use of resources to achieve desired goals and objectives, governments normally initiate economic frameworks, blueprints, roadmaps or plans which guide and coordinate economic activities within the economy. Thus, from 1960 to date, several plans and economic policy reforms aimed at putting the country on the right tract have been undertaken. For instance, four consecutive development plans were formulated and implemented between 1960-1985. The first plan was launched in 1962 and due to the disruptions and distortions caused by the political crises, military coup and the ensuing civil war of independence by the Biafrans, it was extended to 1970. This was successfully followed by the second (1970-1974), third (1975-1980), and the fourth (1980-1985). But in spite of these laudable efforts, evidence in the country tends to suggests that these plans failed to achieve the desired targets of socio-economic transformation of the economy, partly because of poor implementation and where they were vigorously implemented, achievements tend to be disappointing. As shown by Olaniyi (2004), Nigeria's GDP growth rose from about $2 \%$ in the period 1966-69 to $7.6 \%$ in 1970-79, but dipped to 5\% in the period 1980-83; inflation rate increased from $3.8 \%$ in the period 1966-69 to $15.4 \%$ in 1980-83. In another study, Uwatt (2004) showed that unemployment increased from $2.4 \%$ in 1960 to $10.4 \%$ in 1979 from where it reduced to $3.4 \%$ in 1983 , but disappointedly rose again to $8.2 \%$ in 1985 . Similarly, poverty level increased from $28.1 \%$ in 1980 to $46.3 \%$ in 1985 with about 17.7 million and 34.7 million Nigerians wallowing in poverty respectively (see FOS, 1996).

\footnotetext{
${ }^{1}$ This is because, as many have rightly argued, the colonial administrators were more interested in building few infrastructure like the railway that would enable them to easily evacuate primary products from the country (see details in Ikpeze,1978)
} 
Owing to these distortions ${ }^{2}$ and some other structural imbalance in the economy, such as balance of payment deficits, Nigeria adopted the infamous World Bank-inspired Structural Adjustment Programme (SAP) in 1986 as a short term reform programme, whose aims, among others, was to lessen the dominance of the public sector in the management of the economy through the policy thrust of privatization and deregulation, and to achieve internal and external balance, rapid growth and reduction in unemployment and poverty. However, a critical examination of the Nigerian economy during the SAP era indicates that while some improvements were recorded in some areas, most of the traditional economic problems either persisted or deepened and new ones even emerged (CBN, 1993).

With the change in the country's leadership from Babangida to Abacha via a short-lived Interim Government of Shonekan, a comprehensive and well-articulated framework, tagged "Vision 2010" was put forward for Nigeria. Sadly, after a year or so, the vision 2010 dream was abandoned and the social welfare of Nigerians continued to decline (Akpakpan, 2004:22). With the return of democratic rule in 1999, other series of economic reforms were designed to address the structural and institutional weaknesses that have characterized the Nigerian economy. Such reforms were even more necessitated by other emerging challenges of the $21^{\text {st }}$ Century globalised world, one of which is the commitment of the world to accelerate development towards the achievement of the Millennium Development Goals (MDGs) by 2015. Such quest and desire to keep pace with other countries of the world have seen Nigeria moving from one economic framework like the National Economic Empowerment and Development Strategy (NEEDS) to the current Vision 20:2020, from which she desired to be one of the top $20^{\text {th }}$ economy in the world by the year 2020. Unfortunately, Nigeria's socioeconomic progress especially with regards to improving the living standard of the generality of Nigerians still seems to remain largely unimpressive and discouraging (Bulus, 2005).

With the various economic policy reforms or framework so far formulated and implemented in Nigeria, current situations in the country should naturally lead one to ask: Why have socio-economic development in Nigeria been elusive? What lessons (if any) can we draw from past policy development plans and framework? Currently, there is a growing thinking that the 'big size' of the state is the $\operatorname{cog}$ in the wheel of Nigeria's development, and therefore current policy reforms tended to place much emphasis on the market driven economy. Again, the question is: Can Nigeria rightly rely on the market to guarantee her socio-economic progress? The trust of this paper is to seek some plausible answers to these questions. This contribution is done in four more sections, in addition to the present section. In the next section, we present the theoretical framework for the study. Next, we undertake a detailed examination of the various economic policy reforms or frameworks adopted in Nigeria. Thereafter, we draw some reflections on the lessons of past plans/framework. The last section offers some concluding remarks.

\section{Theoretical Framework}

In the management of the national economy, two major but opposing frameworks stand out in the literature: the classical and the Keynesian paradigms. The classical favours the existence of an automatic market and perfectly competitive economy that is free from all government interventions. In their theorizing, it is the market that could guarantee or promote higher level of societal welfare and wealth distribution through efficient allocation of resources, establishment of optimal prizes and effective competition. Greater role is given to the private sector as the prime mover of the economy while the role of government is restricted to the maintenance of law and order and the creation of the necessary institutions and environments for the functioning of the market.

For decades, this theorizing held sway until the serious economic depression of the 1930s dealt a fatal blow to it. There was a massive decline in economic activities and high unemployment rate (Ozughalu,2005) and the classical school had no explanation or prescription to the situation. This led to the emergence of the Keynesian thesis which argued that it was necessary for government to intervene in the management and workings of the economy. Deliberate government intervention was seen as the only panacea to correct the failure of the market forces as well as the concomitant economic maladies.

However, experience across nations, especially in the developing economies, indicates that instances of government failures also abound, for instance, in the persistence of poverty and unemployment, income inequality, malnutrition, budgetary deficits, high inflation, poor economic growth and infrastructural deficiencies, that tend to persist in spite of government intervention. These instances (market and government failures) have given rise to the liberal and the neo-liberal school of thought. While the former thesis posits that the limitations of the market forces could be corrected if government intervenes through some regulatory devices such as private activity regulations, the subsidization policy and strict ministerial control (Obadan and Ayodele,1998), the latter lends support to the classical school by considering government intervention as

\footnotetext{
${ }^{2}$ A distortion can be said to exist in an economy when there is a divergence between policy targets and the actual results.
} 
constituting great impediments to economic development. The proponents of this thesis argued that in most cases, government intervention results in failures that the intervention was meant to correct. Thus, they advocate for increasing reliance on the market through effective privatization and commercialization of existing public enterprises; deregulation of domestic industries and markets and liberalization of trade and banking (Obadan and Ayodele, 1998). The scholarly debate between the neo-liberal school (e.g. World Bank,1996; Williamson,1998; Barnette, 2000), who argued that minimal government in the economy through privatization positively correlate with improved macroeconomic performance and higher real GDP growth and with other things being equal, raise the levels of income, employment and reduce poverty, and the liberal school (e.g. Akpakpan, 2009; Adogamhe,2007; Kohle,2004), who, on the contrary, maintained that privatization and increasing reliance on the market has negative effects on the distribution of wealth and income and has often been manipulated to generate new opportunities for rent seeking and corrupt business practices, in a manner that undermines, rather than enhance economic efficiency and development, is on-going and may not be resolved here. However, the present study adopts the liberal theory as its framework of analysis.

It must be noted that Nigeria has applied virtually all the othordoxy of heavy reliance on the government and the market and a mixture of both at various points in time, with mixed and sometimes, controversial results. This has been reflected in the various economic blueprints formulated or adopted over the years such as the abandoned National Development Plans, Structural Adjustment Programme (SAP), Framework for Economic Development and Planning, National Economic Empowerment and Development Strategy (NEEDS), Seven-point Agenda and the Vision 2020 blueprint.

\section{Nigeria's Development Efforts: Overview Of Some Adopted Frameworks And The Dynamics Of Failures}

Nigeria's economic potential is well recognized. It is also a common truth that in the past decades, it has failed to unlock these potentials. Several efforts made to accelerate the pace of economic development in the country has witnessed more of distortions than solutions to the myriad of socio-economic problems confronting the nation. In this section, we take a look at some of the distortions inherent in past development frameworks.

\section{* National Development Plans}

Since independence, Nigeria has grappled with at least four national development plans. The earliest attempts were the 1946-45 "Ten-Year Plan of Development and Welfare for Nigeria"(with plan revisions,195155) and the 1955-60 plan (later extended to 1962) which were framed by the colonial administrators. However, it has been argued that these plans "were not plans in the true sense of the word...(but) a series of projects which had not been coordinated or related to any overall economic target" (Olayide, 1976:721). The main concentration was the development of physical infrastructure such as rail-roads, motor roads, seaports to facilitate trade between the colony and Britain.

In essence, Nigeria's First National Development Plan was introduced in 1962 and it spanned a period of 7 years (1962-1968). This was followed by the second (1970-1974), third (1975-1980) and fourth (19811985) which all had five years duration. These plans contain some desirable milestones and socio-economic aspirations of the country. For instance, the objectives of the Third National Development Plan were to ensure increase in per capita income, (more) even income distribution, diversification of the economy, reduction in unemployment, and balanced development (Anyanwu, et al., 1997:408). It was during these periods that Nigeria experienced the oil boom which enabled her to embark on ambitious industrialization projects as the main strategy for development. But the economic conditions of the country were threatened when the global oil prices crashed in the early 1980s. The situation was also compounded by another serious problem: food crises arising from the neglect of agriculture. Government responded by adopting a set of desperate short term measures including heavy food importation and external borrowing. External debt in the country rose phenomenally from $\$ 559.2 \mathrm{~m}$ in 1975 to $\$ 24043.0 \mathrm{~m}$ in 1986 (Akpakpan,2004:21).

However, by 1986, the government regarded the fixed five-year planning model as "unrealistic" for the management of the Nigerian economy and decided to adopt a three-tier planning system comprising:

i. A 15 to 20-year perspective plan which (was to) provide a clear vision of where the economy should be at the end of the period as well as addressing the key policies and actions that will be required to translate these "visions" into reality;

ii. A three-year rolling plan $^{3}$ which would derive its bearing from the perspective plan and be subject to annual modification to take account of rapidly changing internal and external environments as well as resources profile of the economy and ;

\footnotetext{
3 The First National Rolling Plan was launched in January,1990 for the period 1990-1992, which was subsequently rolled into the Second (1991-93), Third (1993-95), Fourth (1994-96) and Fifth (1997-99).
} 
iii. An annual budget which would draw its inspiration and programme from the rolling plan.

Many (e.g. Nwankwo, 2003; Muo, 2006; Asiodu, 2009) still believed that if Nigeria did not tinker with the planning strategy, the country could have fared better. In fact, there is a growing consensus that Nigeria had a golden opportunity (through the oil windfall), to turn the tide of her socio-economic misfortunes in the 1970s and 1980s using the planning strategy. However, a combination of various distortions including an overly ambitious industrialization programme (that was heavily import dependence),military coups, political unrest, neglect of the agricultural sector, excessive foreign borrowing, widespread corruption and economic mismanagement caused the economy to rather experienced a prolonged period of economic stagnation and decline. As revealed by Todaro and Smith (2003:73), Nigeria's per capita GDP which grew from $\$ 90$ in 1968 to $\$ 1020$ in 1980 (more than $1000 \%$ increase) was "reversed in the 1980s, so that by 1994, GNP per capita had declined by more than $70 \%$ to $\$ 240$, the same level as in $1972 ”$

\title{
- The Structural Adjustment Programme (SAP)
}

SAP, which was introduced in 1986 as an alternative to the "rejected" IMF loan and its stringent conditions ${ }^{4}$, was the first major economic reform programme in Nigeria and it operated until about 1994. The programme was ostensibly proposed as "an economic package designed to rapidly and effectively transform the national economy" over a period of less than two years (Yesufu, 1996:91). Three factors were proposed as the rationale for the adoption of SAP:

i. excessive dependent of the nation on import, especially consumer goods including food;

ii. total neglect of the domestic production in all five sectors of the economy, namely agriculture, industry, construction, commerce and transportation;

iii. Near total dependence on earnings from oil exports alone for boosting government revenue and foreign exchange reserve (Anyanwu, et al., 1997: 455).

To turn-around the economy, devaluation, deregulation, liberalization, privatization and commercialization became the new economic creed. Nigeria's economic direction and policy thrust was tremendously shaped by external forces such as the IMF. SAP was a major departure from public sector led development strategy. The economy was handed over to the perceived efficiency of the "invisible hand" mechanism; government was encouraged to reduce its expenditure to curb huge fiscal deficit, withdraw state subsidies especially with regards to social services, fertilizer distribution and petroleum products; establish a "realistic" exchange rate for the naira; restore a healthy balance of payments position; privatize its parastatals, and re-position the economy on the path to sustainable non-inflationary growth and development. The fulfillment of all these, amongst others, were made as necessary pre-conditions for debt-rescheduling, debtreduction and inflow of new money from the World Bank, the IMF and the International Community (Anyanwu, et al.,1997:455). SAP was seen as a sole panacea to achieving the desired macro-economic stability and its implementation was done with total vigor such that it became "an end in itself" instead "of a means to an end". Thus "every aspect of our national life-including human beings and their very existence" were "reduced to statistical variables to be manipulated and controlled to achieve macroeconomic stability"(Muo, 2006).

However, a critical examination of the Nigerian economy during the SAP period indicates that while improvements were recorded in few areas, some traditional economic problems persisted and new ones even emerged (CBN, 1993). In other words, the adoption of SAP was a mixture of blessings and woes. As argued by Ndebbio (1991) "in a fair assessment, it is proper to say that SAP carries both pains and joys, but the pains... appear to be greater than the joy". Eventually, SAP was subsequently jettisoned as the regime of Gen. Sani Abacha (1993-1998) abandoned some aspects of the economic package and pursued what it called "guided deregulation". In spite of characterization to the contrary, we have the assurance of the then Minister of Finance that:

\begin{abstract}
"...Our nation is ready and endowed to benefit fully from the wisdom of the market. The philosophy of guided deregulation was never intended to delay the "reign" of the market forces as has been unfairly suggested... It is our own response to the need to ensure that economic growth did not lead to economic grief"' Ani,1998).
\end{abstract}

\section{* Vision 2010}

This was another bold attempt by the Late Gen. Sani Abacha regime to transform the Nigerian economy into "a united, industrious, caring and God-fearing democratic society committed to making the basic needs of life affordable for everyone ... by the year 2010". The vision 2010 was regarded as one of the most comprehensive and well articulated documents on how to unlock the huge potentials of Nigeria and transform

\footnotetext{
${ }^{4}$ However, as rightly observed by Muo (2006), SAP was different from the IMF loan package as six differs from $1 / 2$ dozen
} 
her from an under-developed economy to "an African Tiger" by the year 2010. The plan of action was partitioned into four major horizons: immediate (October- December, 1997); short term (1998-2000), medium term (2001-2005) and long term (2006-2010). The vision 2010 document, which took one year for the 250member committee headed by a seasoned technocrat - Chief Ernest Shoenekan- to produce, contained comprehensive objectives, policies, procedures and road-maps for achieving desirable targets in virtually all sectors of the economy. For instance, it established several desirable milestones in areas such as GDP (10\% growth rate), inflation $(<5 \%)$, population growth rate ( less than $2 \%)$, education and health $(20 \%$ and $10 \%$ of the budget), human development index (0.80), etc. (FGN,1997). The poor socio-economic state of the Nigerian economy compared to other nations which the vision sought to improve is shown in Figure 1 while Table 1 shows other projected social indicators for attainment in the year 2010 .

Figure 1: Human Development Index: Nigeria compared with other Countries (1995)

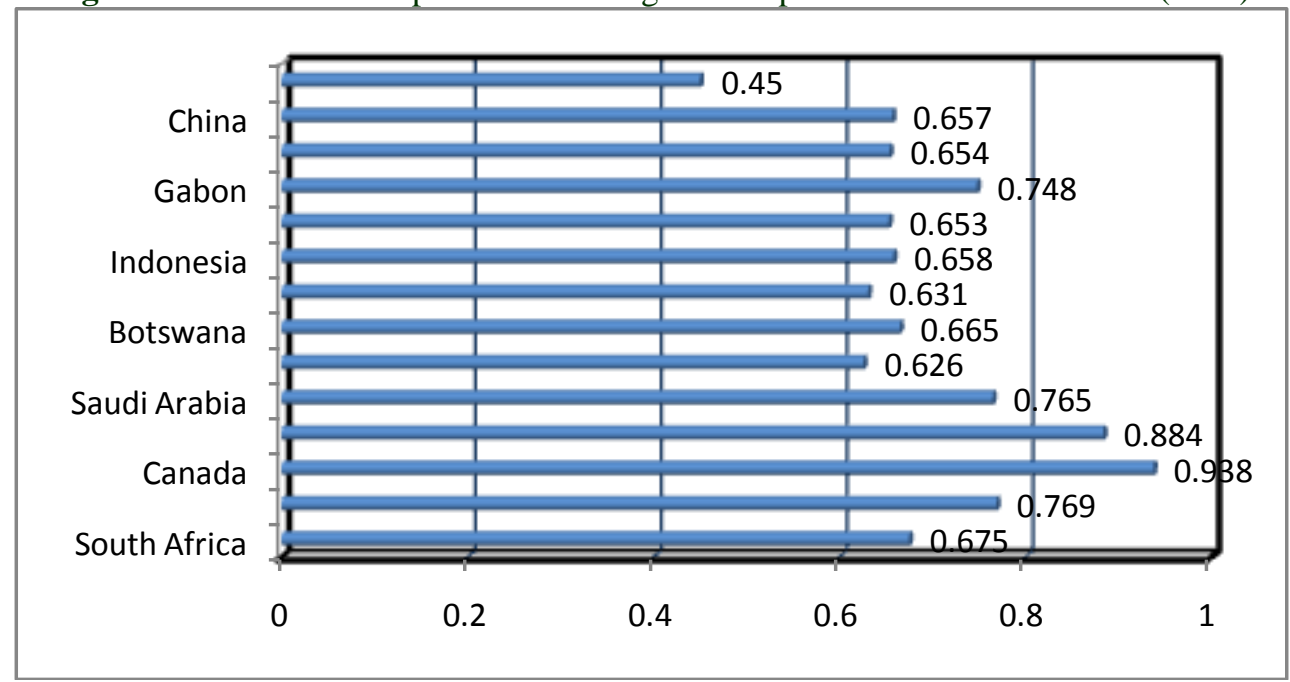

Source : UNDP (2009), Human Development Report, CD ROM

Table 1: Target Social Indicators (1994-2010)

\begin{tabular}{|l|c|c|c|c|c|c|}
\hline & ANICs* & \multicolumn{5}{|c|}{ Nigeria } \\
\hline Social Indicators & 1994 & 1994 & 1998 & 2000 & 2005 & 2010 \\
\hline Per Capita Income at constant & - & - & 420 & 514 & 823 & 1600 \\
1996 Prices (US S) & & & & & & \\
\hline Primary Enrolment Ratio (\%) & 100 & 93 & 95 & 96 & 98 & 100 \\
\hline Secondary Enrolment Ratio (\%) & 65 & 29 & 35 & 39 & 51 & 65 \\
\hline Primary Pupil/Teacher Ratio (\%) & 25 & 39 & 37 & 34 & 29 & 25 \\
\hline Secondary Pupil/Teacher Ratio (\%) & 20 & 38 & 35 & 32 & 25 & 20 \\
\hline Adult Illiteracy Rate (\%) & 13 & 49 & 41 & 34 & 21 & 13 \\
\hline Infant Mortality Rate (per 000 live births) & 26 & 81 & 61 & 53 & 40 & 26 \\
\hline Child Mortality Rate (per 000 live births) & 34 & 191 & 124 & 100 & 58 & 34 \\
\hline Maternal Mortality (per 000 live births) & 32 & 103 & 77 & 66 & 46 & 32 \\
\hline Life Expectancy (years) & 68 & 52 & 53 & 55 & 58 & 62 \\
\hline Access to Safe Water (\%) & 66 & 42 & 43 & 48 & 55 & 66 \\
\hline Access to Health Care (\%) & 94 & 67 & 70 & 74 & 83 & 97 \\
\hline Per Capita Energy Consumption & 1701 & 162 & 227 & 317 & 735 & 1701 \\
\hline Population per Doctor (persons) & 3473 & 5199 & 4908 & 4633 & 4011 & 3473 \\
\hline Population per Nurse (persons) & 467 & 856 & 785 & 720 & 580 & 467 \\
\hline Population per Hosp. Bed (persons) & 747 & 599 & 589 & 613 & 677 & 747 \\
\hline
\end{tabular}

* Average of Newly Industrialized Countries such as Malaysia, Indonesia and Philippines.

Source: Vision 2010's Linkage Group Report (Model Simulation)

However, barely nine months after the committee submitted its reports, Gen. Abacha died suddenly amidst heated controversy over his plan to succeed himself. Before he died, many Nigerians saw the vision 2010 as "a beautiful infant in the hands of a cruel mother- a misbegotten child". However, the question of whether the government of the day could have implemented the plan or not, and to what extent, remains a subject of debate. Gen. Abubarkar, who succeeded him gave himself 11 months to hand over to a civilian administration. This left 
him with no time to do anything with regards to the plan nor introduce any economic reform than to conduct an election which eventually produced Gen. Obasanjo in 1999. The emergence of Obasanjo put paid to vision 2010 document and it remains "a mere vision" as it was abandoned without much consideration for its merit or lack of it. Many analysts believed (and some still do) that if the vision was faithfully implemented, it would have been our surest route to socio-economic el-dorado. In response to the criticisms that trailed the repudiation of the vision 2010 document, the administration decided to create its own blueprint and framework for the transformation of the Nigerian economy.

\section{* Framework for Economic Growth and Development}

This was the first blueprint for economic transformation initiated by the Obasanjo administration in October, 2003. Like in previous roadmaps, the administration took time to outline factors that held back progress in Nigeria as well as bemoaning the poor state of the economy such as low human development and the prevalence of high level of poverty. The ensuing framework was considered to be "simple...multidimensional, consisting of diverse policy measures that will assure prosperity for a strong, united and stable Nigeria" with the Federal Government committing itself to " a prudent and transparent macroeconomic strategy that supports poverty reduction in achieving economic growth and price stability". Several key macroeconomic targets were equally set such as inflation $(<10 \%)$, real GDP growth rate $(7 \%)$, non inflationary money supply growth, complimentary monetary and fiscal policies and budget deficit $(<2 \%)$, etc (FGN, 2002). However, the framework was criticized on many fronts. First, there were complaints that it was hurriedly prepared and secondly it was wrongly timed and lunched at a period that the 2003 general elections were at the front burner. After the election, Nigeria's Economic Adviser replaced and suddenly a new framework for developing the economy was introduced tagged "National Economic Empowerment and Development Strategy (NEEDS)".

\section{* National Economic Empowerment and Development Strategy (NEEDS )}

The formulation of NEEDS was said to be rooted in the lessons of failures of past plans and articulated on a clear vision and a realistic appraisal of what is feasible within the medium to longer term framework. The NEEDS document was also said to be focused on meeting the challenges of the UN Millennium Development Goals, which prescribes that poverty and hunger be halved by 2015. Apart from halving poverty and hunger, other targets of the MDGs include: achieving universal primary education, promoting gender equality and empower women, reducing child mortality, improving maternal health, combating HIV/AIDS, malaria and other diseases, ensuring environmental sustainability, and developing a global partnership for development. Claimed to be broadly owned by Nigerians - with all major stakeholders contributing to its drafting and endorsing its agenda, the document was described as Nigeria's home grown poverty reduction strategy. The NEEDS framework illicit the hope of many Nigerians as it appears to clearly recognized the deteriorating state of the Nigerian economy when it stated the obvious that:

Relative to its own history and in comparison with other countries in Africa and Asia, especially Indonesia which is comparable to Nigeria in most respects, its level of economic development over the decades become more disappointing. With a GDP of about $\$ 45$ billion in 2001, and a per capita income of about $\$ 300$, Nigeria has become one of the poorest countries in the world. As at 2000, Nigeria has earned approximately $\$ 3000$ billion from oil exports since the mid 1970s, but its per capita income was 20\% less than the 1975 level (NPC, 2004:19)

Other various (daunting) development challenges which NEEDS recognized and sought to address are shown in Box 1. The NEEDS blueprint clearly noted that the social conditions in Nigeria present a startling paradox one at which the level of poverty of her people stood in contrast to the country's vast wealth. The strategy thrust of NEEDS to revitalize the weakened social pillar was to grow the private sector, turning it into an instrument of wealth creation, employment generation and poverty reduction. The role of the government was that of facilitation and providing the enabling environment for the private sector to invest and operate in a free market system. In other words, the government is to withdraw from the commanding heights of the economy through a more vigorous pursuit of deregulation, liberalization and privatization.

Unarguably, NEEDS, like other previous plans or framework, contains several desirable targets for attainment in various domains. Some of these include the creation of 2 million jobs by 2007 ( 1 million in 2004 and 2 million annually from 2005 to 2007); GDP growth of 5\%,6\% and 7\% in 2004-2007; inflation rate of 9\% by 2007 from $15 \%$ in 2003; external reserves of $\$ 10.6$ billion by 2007 ; adult literacy rate from $57 \%$ to $65 \%$ by 2007; electricity generation of 10,000 watts by 2007 , access to safe water from $64.1 \%$ in 2003 to $70 \%$ by 2007 ; HIV prevalence rate from $6.1 \%$ to $5 \%$, etc. To achieve all these, Nigerians were not only assured that "...the implementation strategy is better articulated, and the commitment to effective implementation is unprecedented", but were also informed that NEEDS is a feasible plan,...the targets for progress are realistic, 
not "pie in the sky" objectives that will never be achieved (NPC,2005: xiii). NEEDS was expected to be a medium term framework (2003-2007), after which it was to be revised and sustained for the next four years (2008-2011). Similar frameworks were also expected to be developed and adopted at the state and local governments.

\begin{tabular}{|c|c|}
\hline & Box 1: The Development Challenges Facing Nigeria \\
\hline & \\
\hline$>$ & Per capita GDP in Nigeria was among the lowest in the world. It remained stagnant in the 1990s, \\
\hline & and grew by just $2.2 \%$ between 1999 and 2003 . \\
\hline$>$ & Nigeria's urbanization rate - about $5.3 \%$ a year - is one of the fastest in the world. \\
\hline$>$ & The educational system is dysfunctional, as graduates of many institutions cannot meet the needs \\
\hline & of the country. Institutions are in decay, strikes and cultism are common. \\
\hline$>$ & As at 1999 , more than $70 \%$ of Nigerians were estimated to lived in poverty while only $10 \%$ of the \\
\hline & population had access to essential drugs. \\
\hline$>$ & Life expectancy is mere 54 years, and infant mortality (77 per 1000) and maternal mortality (704 \\
\hline & per 100,000 live births) are among highest in the world. \\
\hline$>$ & Physicians per 100,000 persons were fewer than 30 . \\
\hline$>$ & Only about half of the population had access to safe drinking water $(40 \%$ in rural areas, $80 \%$ in \\
\hline & urban areas). \\
\hline$>$ & Rent-seeking and corruption were pervasive. \\
\hline$>$ & Inadequate and decaying infrastructure. \\
\hline$>$ & Weak institutional capacity for economic policy management and coordination. \\
\hline$>$ & Actual daily power generation fell to less than 2000 megawatts (MW) in 1999 \\
\hline r & : Compiled by the Authors from National Planning Commission (2005) \\
\hline
\end{tabular}

However, an evaluation of the performance of the Nigerian economy under NEEDS by Obadan (2009) indicates that while significant improvements in growth and macroeconomic stability were recorded, most of these lofty targets especially with respect to power generation and other social indicators were not achieved. To date, it is becoming glaring that Nigeria is far from meeting the targets of the MDGs (Essien and Akpan, 2009). Also, while some states/local governments have spent huge sum of public money to draft their own SEEDS and LEEDS documents, their implementation (if any) across the nation also leaves much to be desired. Besides, the prominence given to deregulation and privatization in NEEDS based on the perceived superiority of the private sector in providing efficient goods and services that were earlier deemed to be the exclusive preserve of the public sector, raised more questions than answers. Many have argued that the nation's private sector is not strong enough to unleash the needed stimulus for socio-economic progress. Another common perception is that there are few winners with many losers in the privatization process. As argued by Adogamhe ( 2007), privatization is a controversial policy which has enriched the few at the expense of the vast majority of the poor; provide benefits to "new private owners" while benefits to "consumers and citizens" are small and uncertain, sometimes never emerging at all, at least in the short-run. As remarked by CDD(2008), "NEEDS created a contradictory legacy" because in spite of some success in macro-economic stability, the poor did not benefit from it due to its market driven model that makes it impossible to achieve the noble aims of the NEEDS social charter which seems to cast it in the mold of past World Bank inspired Structural Adjustment Programme. Thus, many have cautioned that for a developing country like Nigeria, where market imperfections are a norm rather than the exception, the unlimited application of the "magic of the market" only succeeds in creating far-reaching distortions without achieving the desired growth and development (Obadan, 1993). But the proponents of the deregulation and privatization policies still believed that Nigeria cannot achieve much progress without them! To them, these will allow governments to concentrate resources on their core functions and responsibilities, while enforcing the rule of the game so that the market can work efficiently.

Before Yar'Adua took over on May 29, 2007, the architect of NEEDS - Charles Soludo was replaced in quick succession by Ode Ojowe and then by Osita Ogbu as Economic Advisers to the government. Expectedly, just like most of his pre-successors, the administration of Yar'Adua wasted no time in introducing his own blueprint or political slogan tagged "7 Point Agenda" which became the new economic creed of the government.

\section{- Yar'Adua's 7 Point Agenda}

Just like many of his pre-successors, the administration of Yar'Adua wasted no time in introducing its own blueprint or political slogan tagged "7 Point Agenda". In spite of the existence of NEEDS II (2008-2011), the 7point agenda was initiated by the Yar'Adua administration as the framework to guide governments on how to manage the Nigerian economy and accelerate her transition unto the path of sustainable growth and development. The seven key areas of priority in the agenda include: 
(i) Power and Energy: Admitting that there cannot be any meaningful development without steady power supply, the administration promised to lunch "a national emergency programme" on the sector. The target was to increase power supply to 10,000 megawatts before the end of 2008 (the same target set for achievement in 2007 under NEEDS) and at least 30,000 megawatts in 2011 and 50,000 megawatts by 2015.

(ii) Food Security: This was to be realized through committing "heavy investment" into agriculture, to increase productivity and revolutionize agricultural technology that will generate a 5-10 fold increase in yield and food production.

(iii) Wealth Creation: This was to be done through a diversified production especially in the agricultural and solid mineral sector.

(iv) Transport Sector: Recognizing the fact that Nigeria's transportation sector is characterized by poor road network and inefficient rail system and waterways, this agenda aimed to rehabilitate and modernized the country's railways and construct new road network across the country as well as constant rehabilitation of existing ones.

(v) Land Reforms: The main thrust of the land reform agenda is to change the existing land laws in order to optimize Nigeria's growth through the release of land for commercial farming and other large scale business by the private sector.

(vi) Security: The government was oblivious of the fact that no genuine investment or development could thrive under the state of insecurity, thus this agenda was aimed at improving the investment climate in the country, particularly in the Niger Delta region.

(vii) Education: Education is universally recognized as the bedrock of development. The reform agenda in the educational sector was said to be two-fold: (i) to ensure minimum acceptable international standards of education for all, and (ii) to develop a strategic educational development plan that will ensure excellence in both the tutoring and learning of skills in science and technology by students who will be seen as the future innovators and industrialists of Nigeria. This reform was to be achieved through massive injection of funds into the educational sector.

With these, the administration hoped to lift the economy from the doldrums into the path of sustainable growth and development. While many analysts believed that the agenda reflects some of the key issues that needed to be addressed if the nation must and should move forward, experience in Nigeria have indicated that mere having a road map or an economic blueprint cannot guarantee a surest route to socio-economic transformation if the political will for its implementation is lacking. Up till today, the objectives of the 7-point agenda are far from being realized. Just as the high hopes of Nigerians were raised by previous roadmaps only to be dashed, it is sad to note that for almost three years after the promised declaration of state of emergency on the power sector, nothing has happened. The same seems to be the case for the other areas of action, except the relative stability in the Niger Delta via the amnesty project. Besides, the agenda tends to lack a clear and comprehensive policy direction on how these goals could be achieved. While the major concern for security was directed at the Niger Delta, other areas like Jos and Bauchi were tearing apart, with many lives and properties lost. Similarly, there was no specific mention of how poverty which is one of the most difficult challenges in Nigeria would be tackled. The health sector was conspicuously left out from the agenda not minding the deplorable state of the sector across the country. Besides, the extent to which the Yar'Adua administration could have transformed the 7-point agenda into reality at the end of the four-year period have been overtaken by event.

\section{* Vision 20:2020}

Vision 20:2020 represents another attempt by Nigeria to join the league of 20 industrialized nations by the year 2020. The Nigeria Vision 20:2020 economic transformation blueprint is a ten year plan for addressing the distortions in the economy and stimulating its economic progress onto the path of sustained and rapid economic growth and development by 2020.To attain this overarching goal of being one of the 20 largest economies in the world by year 2020, Nigeria is expected to enhance her economic development performance as illustrated by (but not limited to) the under-listed key parameters.

Table 2: Key Parameters and the Expected Performance by 2020

\begin{tabular}{|c|l|}
\hline Key Areas & \multicolumn{1}{c|}{ Expected Outcome } \\
\hline Polity & By 2020, the country will be peaceful, harmonious and a stable democracy \\
\hline Macro-economy & $\begin{array}{l}\text { A sound, stable and globally competitive economy with a GDP of not less than \$900 } \\
\text { billion and a per capita income of not less than \$4000 per annum }\end{array}$ \\
\hline
\end{tabular}




\begin{tabular}{|c|l|}
\hline Infrastructure & $\begin{array}{l}\text { Adequate infrastructure services that support the full mobilization of all economic } \\
\text { sectors }\end{array}$ \\
\hline Education & $\begin{array}{l}\text { Modern and vibrant education system which provides for every Nigerian the } \\
\text { opportunity and facility to achieve his maximum potential and provides the country } \\
\text { with adequate and competent manpower }\end{array}$ \\
\hline Health & $\begin{array}{l}\text { A health sector that supports and sustain a life expectancy of not less than } 70 \text { years } \\
\text { and reduces to the barest minimum the burden of infectious diseases such as malaria, } \\
\text { HIV/AIDS and other debilitating diseases. }\end{array}$ \\
\hline Agriculture & $\begin{array}{l}\text { A modern technologically enabled agricultural sector that fully exploits the vast } \\
\text { agricultural resources of the country to ensure national food security and contributes } \\
\text { significantly to foreign exchange earnings. }\end{array}$ \\
\hline Manufacturing & $\begin{array}{l}\text { Vibrant and globally competitive manufacturing sector that contributes significantly } \\
\text { to GDP with a manufacturing value added of not less than } 40 \%\end{array}$ \\
\hline
\end{tabular}

Source: National Planning Commission (2009), Draft Documents of Vision 20:2020

Table 3 presents some projected macro-economic variables from 2010 to 2020. Within the period, GDP is expected to grow by $16.5 \%$, gross fixed capital formation by $42.1 \%$, while the rate of inflation is expected to average $19.1 \%$. Similarly, the rate of unemployment is expected to progressively decline from $10.43 \%$ in 2010 to $7.54 \%$ in 2020 . Currently, the Vision $20: 2020$ is being considered as the major framework of national development that will transform our country into what it always promised but never delivered. But against the backdrop of the country's failure with past development frameworks, the unanimous question seems to remain: will Vision 20:2020 be any different or produce different results?

Table 3: Nigeria’s Projected Macro-economic Variables for Vision 20:2020 (\%)

\begin{tabular}{|l|l|l|l|l|l|l|l|l|l|l|l|l|}
\hline & 2010 & 2011 & 2012 & 2013 & 2014 & 2015 & 2016 & 2017 & 2018 & 2019 & 2020 & Average* $^{*}$ \\
\hline GDP & 6.1 & 5.9 & 6.0 & 7.2 & 9.2 & 11.1 & 12.6 & 14.4 & 16.8 & 20 & 23.8 & 12.1 \\
\hline $\begin{array}{l}\text { Gross Fixed } \\
\text { Capital } \\
\text { formation }\end{array}$ & 34.0 & 34.8 & 35.7 & 36.8 & 38.2 & 39.5 & 40.6 & 41.4 & 42.1 & 42.8 & 44.2 & \\
\hline $\begin{array}{l}\text { Government } \\
\text { Consumption }\end{array}$ & 7.3 & 7.0 & 8.2 & 10.3 & 12.9 & 15.4 & 17.3 & 19.5 & 22.5 & 26.4 & 31.1 & 39.1 \\
\hline $\begin{array}{l}\text { Private } \\
\text { Consumption }\end{array}$ & 18.8 & 16.7 & 16.8 & 19.5 & 24.0 & 28.5 & 31.1 & 36.4 & 42.7 & 51.0 & 61.5 & 16.2 \\
\hline Revenue & 11.0 & 7.7 & 5.4 & 5.6 & 7.4 & 8.2 & 7.0 & 5.4 & 4.7 & 5.3 & 6.6 & 6.8 \\
\hline $\begin{array}{l}\text { Government } \\
\text { expenditure }\end{array}$ & 7.9 & 6.1 & 4.4 & 4.9 & 6.7 & 7.7 & 7 & 5.9 & 5.9 & 7.3 & 9.7 & 6.7 \\
\hline Exports & 16.6 & 11.4 & 7.6 & 8.0 & 11.0 & 12.3 & 10.4 & 7.6 & 6.5 & 7.5 & 9.0 & 9.8 \\
\hline Imports & 7.2 & 8.2 & 8.9 & 11.1 & 14.0 & 16.3 & 17.9 & 19.5 & 21.9 & 25.0 & 28.6 & 16.2 \\
\hline Inflation & 11.2 & 9.4 & 9.3 & 10.4 & 12.1 & 13.8 & 15.2 & 16.8 & 19.1 & 22.2 & 26.0 & 15.0 \\
\hline $\begin{array}{l}\text { Unemployment } \\
10.43\end{array}$ & 10.33 & 9.61 & 9.33 & 9.07 & 8.81 & 8.55 & 8.30 & 8.04 & 7.79 & 7.54 & 8.9 \\
\hline
\end{tabular}

*calculated by the Authors

Source: Ekpo (2009)

Table 4 which compares Nigeria with some top 20 economies of the world as at 2007 indicates that the challenges of joining the league of 20 highly developed nations in 2020 seems ambitious and a daunting one. With a human development index of 0.511 , life expectancy of 47.7 years and per capita GDP of US\$1969, the country does not only compare unfavorably with not only the highly industrialized nations as shown in Table 4 but even with other African countries like South Africa(0.688), Ghana (0.526), Sudan (0.532), Madagascar (0.543), Congo (0.610) , Namibia (0.686), Botswana (0.694), and Egypt (0.703) in terms of human development (HDR, 2009, CD ROM). Out of 182 countries, Nigeria ranks 158 and occupies the bottom of medium human development countries. An examination of the structural and macroeconomic fundamentals of the Nigerian economy by Ekpo (2009) shows that the Nigerian economy is backward ${ }^{5}$. The most threatening and worrisome is the current spate of insecurity in the country due to the Boko Haram sect. This has the effect of reversing any meaningful gains recorded and puts the attainment of the vision in serious jeopardy.

\footnotetext{
${ }^{5}$ See Ekpo(2009) for the data vis-à-vis other countries like Indonesia, Netherlands, Belgium, Poland, and Turkey.
} 
Table 4: Socio-Economic Characteristics of Nigeria and 16 top 20 economies of the World (2007)

\begin{tabular}{|c|c|c|c|c|c|c|}
\hline Countries & HDI & $\begin{array}{c}\text { Life } \\
\text { Expectancy } \\
\text { At Birth }\end{array}$ & $\begin{array}{l}\text { GDP per capita } \\
\text { (PPP US\$) }\end{array}$ & $\begin{array}{l}\text { Combined Gross } \\
\text { Enrolment Ratio } \\
\text { in education }\end{array}$ & Gini Index & $\begin{array}{l}\text { Rank in Human } \\
\text { Poverty Index }\end{array}$ \\
\hline Norway & 0.971 & 80.5 & 53,433 & 98.6 & 25.8 & 2 \\
\hline Australia & 0.970 & 81.4 & 34,923 & 114.2 & 35.2 & 14 \\
\hline Canada & 0.970 & 80.6 & 35,812 & 99.3 & 32.6 & 12 \\
\hline Ireland & 0.965 & 79.7 & 44,613 & 97.6 & 34.3 & 23 \\
\hline Netherlands & 0.964 & 79.8 & 38,694 & 97.5 & 30.9 & 3 \\
\hline Sweden & 0.963 & 80.8 & 36,712 & 94.3 & 25.0 & 1 \\
\hline France & 0.961 & 81.0 & 33,674 & 95.4 & 32.7 & 8 \\
\hline Switzerland & 0.960 & 81.7 & 40,658 & 82.7 & 33.7 & 7 \\
\hline Japan & 0.960 & 82.7 & 33,632 & 86.6 & 24.9 & 13 \\
\hline Luxembourg & 0.960 & 79.4 & 79,485 & 94.4 & 30.8 & 10 \\
\hline Singapore & 0.944 & 80.2 & 49,704 & Na & 42.5 & 14 \\
\hline USA & 0.956 & 79.1 & 45,592 & 92.4 & 40.8 & 22 \\
\hline Spain & 0.955 & 80.7 & 31,560 & 96.5 & 34.7 & 17 \\
\hline Turkey & 0.806 & 71.7 & 12,955 & 71.1 & 43.2 & 40 \\
\hline Chile & 0.878 & 78.5 & 13,880 & 82.5 & 52.0 & 10 \\
\hline Poland & 0.880 & 75.5 & 15,987 & 87.7 & 34.9 & - \\
\hline Nigeria & $\mathbf{0 . 5 1 1}$ & $\mathbf{4 7 . 7}$ & $\mathbf{1 , 9 6 9}$ & $\mathbf{5 3 . 0 0}$ & $\mathbf{4 2 . 9}$ & $\mathbf{1 1 4}$ \\
\hline
\end{tabular}

Source: UNDP(2009), Human Development Report, CD ROM.

\section{The Journey So Far: What Have We Learnt From History?}

Nigerian economy has experienced more distortions on its che-quered history of searching for a right strategy for ushering in the country's development. As earlier said, any factor that hinders the operation of the economy at its optimal level represents a distortion. There are several lessons we can draw from the various economic frameworks or blueprints adopted in the country so far. In other words, why did previous experiments failed to lead us to the Promised Land? This, of course, is a million naira question to which every economist in Nigeria has his own explanation. The list is endless and most of them are well known facts. We do not pretend to have exhausted all the issues, rather a few of them are as discussed below.

(i) Frequent changes of the Roadmap: The framework or roadmap for unlocking Nigeria's great potential for greatness have increasingly become unstable over the years, making the attainment of the goal of economic development difficult. There is a growing penchant for Nigerian administrators (politicians) to always attempt to "do something new" regardless of the merit or otherwise of the existing blueprint initiated by their predecessors. It is a paradox to note that each one of these "bagful" of past strategies or roadmaps has always been hailed as comprehensive, well articulated and realistic, especially at the time they were articulated. Yet proponents of succeeding roadmaps will always found reasons to discredit and jettison them and embark on new ones. As rightly observed by the 1996 UNDP report "it is no coincidence that various military and civilian governments of Nigeria have repeatedly announced new policies on virtually every aspect of the national life and there is no doubt that they will continue to do so in the future". It is sad to note that such embarrassing level of policy turnover has not resulted in significant improvement in the life of Nigerians.

(ii) Poor Implementation, non-implementation or out-right sabotage: A review of the past frameworks tends to confirm that one of the major problem of Nigeria's backwardness is not in the existence of a roadmap or lack of it. It is not also the lack of ideas on how to get to where Nigeria desired to be. Most often, the journey is often truncated as a result of poor implementation, non-implementation or even out-right sabotage. In other words, it is either "the drivers" using the roadmaps do not use it as directed or they have refused to use it or ensure that they don't use it at all. This was particularly the case with the well articulated Vision 2010 which had some commendable goals that could have helped the nation to march forward to greatness if it was logically executed.

(iii) The Leadership Question: Listening to the broadcast of all the coup plotters in Nigeria and presidential candidates in their electioneering campaigns, their reasons for effecting or seeking a change in leadership have always been summarized in three key words: economy, governance and corruption. Unfortunately, for the past years of its independence, Nigeria has not been lucky to have a good, strong and committed leadership. Obviously, a country that has an abundant resources without good leadership cannot move in the path of development. Experience has shown that when a country's leaders in a stable government are strongly devoted to development, inadequacies in the particular type of plan or framework in use or even the lack of any formal planning will not seriously impede the country's development. Conversely, in the 
absence of good leadership or stability, the most advance form of planning or a well articulated framework/vision will not make any significant contribution towards development. Corruption which constitutes a fiscal termite on Nigeria's development effort still remains one of the most discussed policy distortions in Nigeria.

(iv) Increased Gravitation towards a Free Market Economy: Since the introduction of SAP, macro-economic policies geared towards enhancing the efficiency of the price mechanism have dominated thinking in policy-making cycles in Nigeria. The virtues of a market system with a sound and functional price system have been strongly extolled in virtually all the succeeding frameworks. Less government intervention is being traded for the inflow of external assistance. Bureaucratic failures have provided a basis for the intensified transition to the free enterprise economy. But as pointed out by Obadan (1993), a developing country like Nigeria with all the well-known market imperfections cannot afford the distortions created by unbridled market forces. Markets in Nigeria like in other developing countries are permeated by imperfections. Commodity and factor markets are poorly organized and the existence of "distorted prices" leads to inefficiency in production and distribution. Our experience with this market model may have increased Nigeria's GDP, maintain some macro-economic stability, but as far as the social conditions of an average Nigerian is concerned, it has failed to yield the desired result. Rather, far-reaching distortions have been created. Social services have virtually crumbled because of large cuts in government spending, income distribution pattern is exacerbated, the cost of living have sky-rocketed, unemployment have trended upwards due to the wave of privatization and downsizing. From the pages of history, no country has developed without the active involvement of government directing, coordinating and leading the way.

(v) Development as a "Federal Affair": Economic frameworks and roadmaps are increasingly being seen as a Federal Government issue. Some states and local government areas merely assumes the status of spectators in the development arena. Some do not even understand the true meaning of development. As Soludo (2005) observed, most states spend more than $80 \%$ of their Federation Account allocations on recurrent expenditure, leaving them with very little to spend on basic infrastructure and social services. Most local governments do not have any vision or development plan. Instead, they only exist as an avenue for sharing "the national cake" and "warming up" for the next election. Because of the battered social values, the communities condoned and openly cerebrated them in so far as "their son" brought home and share the loots from the public treasury. Most often, people are literally ostracized by their communities for going into government and returning with "empty hand". Hence, the question: what are the roles of the states and local governments in achieving the current Vision 20:2020 will largely remain unanswered at the local and state levels, because "it is a federal affair".

(vi) Over-dependence on oil: Nigeria's economic fortunes and financing of development plans has continue to be tied to the vagaries of the oil prices. Even when the economic danger of such situation have been noted, nothing significant have been done to diversify the economy. Past planning experience in the 70s failed partly because of the crash in the world's oil prices which grounded the industrialization programme and pushed the country into huge external debt (Akpakpan, 2004) and yet the country seem not to have learnt its lessons.

(vii) Politicizing Development: The political class (democratic and military) has shaped the nation's economic successes as well as its failures since independence. Sometimes, good economic packages or roadmaps are reduced to the level of politics. Most politicians (democratic and military) tend to be more preoccupied with securing their "tenure" rather than bothered about implementing economic development programmes or packages. Politicians have lied repeatedly in the past to the electorate during electioneering campaigns to the extent that an average person in Nigeria is forced to believe that politics is synonymous with lying. Most often, their true objectives in government usually differ from their public pronouncements; economic plans, frameworks or roadmaps are sometimes used for public relation purposes which may not reflect the true priorities of the rulers. Private gains override public interest. Economic policies can only be implemented when there are immediate or direct private returns. The salient truth can be discerned from the following remarks by Garba(1995:237):

In a country like Nigeria where the prizes are so few, and the stakes are so high, the fight for booty or 'national cake' fierce and often vicious. It has at times led to a debilitating corruption in the arena of public policy making and implementation...more often than not, the distributional consequences of public policies are the intended result of the private interests which have been instrumental in their design, passage and implementation. For the entire country, the manipulation of public policy for private purposes comprises yet another disjunction in our fractured history. Not every public policy fails and not every public programme or project is redundant. But when once in a while a policy succeeds, it is often not because of government per se, but in spite of it.

In view of this, the easiest pastime to adopt by Nigerians is skepticism - one that sees every effort in national regeneration as a usual rhetoric and a mere waste of time. This tends to explain why people tend 
to disbelieve everything coming from the government. Many are equally skeptic that the current Vision 20:2020 may not be anything different. Under such condition, it becomes increasingly difficult to engender national consensus about development programmes by enlisting grassroots' cooperation, support and enthusiasm, who being very poor and often mistrusting the government may prefer more consumption today to future growth.

(viii) High Turnover of Economic Roadmap Operators: Just as the framework for Nigeria's economic development are changing by the day, the operators were also changing. For instance, within the past 10 years, we have had Phillip Asiodu, Magnus Kpakol, Charles Soludo, Ode Ojowu, Osita Ogbu, Tanimu Yakubu Kurfi, Prof. Garba, and Dr. Nwanze Okidegbe, in quick succession occupying the sensitive post of Economic Adviser for Nigeria. Whereas these Nigerians may well have been experienced and capable, the turnover is embarrassing. Given their own philosophy on how best to move the nation forward, such frequent changes only breads the tendency to always "do something new" and the economy as observed by Muo(2006) has not been better for it.

\section{Concluding Remarks And The Way Forward}

We have reviewed the various frameworks or roadmaps fashioned to unlock Nigeria's untapped and rich potentials for sustainable growth and development over the years. Although most of these strategies were not without any merit, current situations tend to confirm that not much has been achieved. A combination of various distortions has forced Nigeria to dance around the vicious cycle of economic backwardness. What hopes for Nigeria? What hopes for the realization of Vision 20:2020? Given Nigeria's well recognized potentials, there is hope for the country to achieve remarkable success in the next couple of years. Nigeria only needs to be consistent, determined and focused. Frequent changes of the roadmap will only create further distortions in the economy. Even though Nigeria missed to land among the top 20 economies of the world in 2020 (since these countries and many others would not remain stagnant), it should learned from history and avoid all the mistakes of the past. The Vision 20:2020 is desirable but it is not an end in itself rather a means to an end. A strong political will and sincere implementation remains a necessary condition for achieving the objectives of the vision. Without good governance and enthronement of accountability, this vision will remain at the realm of myth. Thus, the "drivers" using the Visions' roadmap should be sincerely committed to the journey/destination and "ply the road as mapped". In this vain, there is need to clearly articulate the legal framework for the implementation of the roadmap. Effective monitoring and evaluation is also necessary to track progress.

One basic lesson from history is that there is no easy and quick template to greatness. All great nations of the world keep doing a few things right for a sustained period of time (Soludo, 2005) and therefore Nigeria cannot be an exception. A technical knockout of corruption from all spheres of our national life must be pursued and sustained. There is need to ensure a broad and clear understanding of government policies and intentions. This will require seminars, discussions and broad communication in order to enlighten all on government plans and policies.

We acknowledge that neither the market nor the government can produce perfection. Both breed different distortions. There is no doubt that the Nigerian economy needs to be freed from corrupt and inefficient bureaucracy in order to lead to meaningful development. But a private sector-driven economy is not necessarily the solution. The current experience from the fall-out of the global economic meltdown should force us to rethink the unguided market driven economic theorizing. The government should not be wary of intervening in the economy when and where it is necessary, mostly in fixing the infrastructural and energy problem, revamping the untapped solid minerals and agricultural potentials , massive investment in human capital development and other social services, amongst others. The free market may still be the ultimate convergent point in the long-run when the country is fully industrialized and minimally poor (perhaps by the year 2020). But for now, our economic reforms should 'wear a human face' by providing safety nets for the vulnerable and others affected by such reforms.

We may not have exhausted all the recommendations. Most of the solutions we suggest here are not new. Many others have long been painstakingly discussed elsewhere (see NES, 1997).But sometimes the problem is often not on "the how to do it" but "the will to do it". The truth however remains that Nigeria has all it takes to make progress and break away from this cycle of economic backwardness, if at all it could learnt something from its past mistakes. Given the popular frustration about the economic outcome of the various roadmaps so far, the key question is whether the present administration has the political will to carry out to the letter the beautiful and ambitious goals which the Vision 2020 document carries. The answer to this question is vital, otherwise the document may as well pass as another déjà vu!

\section{References}


[1] Adogamhe, P. (2007), "The Nigerian National Economic Empowerment and Development Strategy (NEEDS): A Critical Assessment", A Paper Delivered at the $48^{\text {th }}$ Annual Convention of International Studies Association, Chicago, USA, February $28^{\text {th }}-3^{\text {rd }}$ March.

[2] Akpakpan, E.B. (2004), “The Struggle for Development: Why Have Some People been so Unsuccessful?”, $10^{\text {th }}$ Inaugural Lecture of University of Uyo, August 19, 2004.

[3] Akpakpan, E.B. (2009) “Economics and the Global Financial Crisis: Towards a Reconstruction", Paper presented at the 50the Annual Conference of NES, Abuja, September.

[4] Ani, A A (1998), "1998 Budget Briefing", The Guardian, January 7.

[5] Anyanwu, J. C., A. Oyefusi, H. Oaikhenan, and F.A. Dimowo (1997), The Structure of the Nigerian Economy (1960-1997), Onitsha: Joanee Educational Publishers Ltd.

[6] Asiodu, P.C. (2009), "Chairman's Opening Remarks", In: Nigeria's Development In Time Perspective: Past, Present \& Future" Selected Papers for the 2007 Annual Conference of NES, Pp. 11-19.

[7] Barnette, S. (2000), "Evidence on the Fiscal and Macro-economic Impact of Privatization", IMF Working Paper, Washington DC: Fiscal Affairs Department.

[8] Bulus, Y.D. (2005), "Economic Deregulation and the Incidence of Market Failures: Some Reflections on the Liberalization of the Nigerian Economy" In: Cost and Benefits of Economic Reforms in Nigeria. Selected papers for the 2005 Annual Conference of NES. Pp. 117-148.

[9] Central Bank of Nigeria(1993), Perspectives of Economic Policy Reforms in Nigeria, Lagos: Page Publishers Services Ltd.

[10] Centre for Democracy and Development(CDD)(2008), Vision 20:2020 and Nigeria's Poverty Eradication Strategy: Re-energizing the Policy Agenda, CDD, European Union

[11] Essien, E. B. and U. F. Akpan (2009), Global Economy in Crises: Pressure on achieving the Millennium Development Goals in Nigeria. Paper Presented at the $50^{\text {th }}$ Annual Conference of the Nigerian Economic Society, $28^{\text {th }}-30^{\text {th }}$ September, Abuja,

[12] Ekpo, A.H. (2009), "Global Economic Meltdown and National Vision 20:2020", Paper Presented at the Annual Conference of the Nigerian Society of Engineers at Disney Hotel and Resort, Owerri, $7^{\text {th }}$ December,2009.

[13] Federal Government of Nigeria (1997), Report of Vision 2010 Committee, Lagos: Government Press

[14] Federal Government of Nigeria (2002), "Framework For Nigeria's Economic Growth and Development", Abuja: FGN

[15] Federal Government of Nigeria (2002), Framework for Economic Growth and Development, Abuja: FGN.

[16] Federal Office of Statistics (1996), Annual Abstract of Statistics, Lagos: FOS.

[17] Garba, J. (1995), Fractured History: Elite Shifts and Policy Changes in Nigeria, Princeton: Sungai Books

[18] Ikpeze, N. (1978), "The Role of Government in Aggregative Planning" In: The Nigerian Journal of Economic and Social Studies, Vol. 20, No. 2. July. Pp. 28-36

[19] Kohle, A. (2004), "Dashed Expectation: Nigeria in State Directed Development" In: Political Power and Industrialization in the Global Periphery. Cambridge: Cambridge University Press. Pp. 291-366

[20] Muo, I. (2006), "Macroeconomic Policies in Nigeria: Lessons from History and the Way Forward" In: Analysis of Macro-economic Policies In Nigeria (1960-2006), Zenith Economic Quarterly, Vol. 2. No.8, October.

[21] National Planning Commission (2004), National Economic Empowerment and Development Strategy (NEEDS),Nigeria, Abuja: NPC

[22] National Planning Commission (2005), National Economic Empowerment and Development Strategy (NEEDS), Nigeria, Abuja: NPC

[23] Ndebbio, J.U.E. (1991), “Assessing Nigeria's Structural Adjustment Programme Three Years After Its Introduction”, In: Ndebbio, J.U.E and A.H.Ekpo(eds), The Nigerian Economy at the Crossroads: Policy and their Effectiveness Calabar: University of Calabar Press.

[24] Nigeria Economic Society (NES)(1997), Why Have Economic Policies Failed in Nigeria, Ibadan:NES

[25] Nwankwo, G. O. (2003), The Grammars of Management: The Nigerian Experience, Lagos: Evergreen Associates.

[26] Obadan, M. I. (1993), "The Workings of a Free Enterprise Economy", In: Managing a Free Enterprise Economy, Ibadan: NES , Pp. 7-27.

[27] Obadan, M. I. and A. Ayodele (1998), Commercialization and Privatization Policy in Nigeria, Ibadan: NCEMA

[28] Obadan, M.I. (2009), "A Review of Recent Economic Management in Nigeria”. A Paper Presented at the 50th Annual Conference of NES, Abuja, $22^{\text {nd }}-24^{\text {th }}$ September.

[29] Olaniyi, O. (2004), "Regime Types and Macroeconomic Policy Effectiveness in Nigeria (1960-1999), In: Garba, A, et al (eds), Leading Issues in Macro-economic Management and Development, Ibadan: NES, Pp. 353-367.

[30] Olayide, S.O. (1976), Economic Survey of Nigeria (1960-1975), Ibadan: Aromolaran Publishing Company Limited

[31] Ozughalu, U. M. (2005), "The Glories and Woes of Public Enterprises Reforms in Nigeria" In: Costs and Benefits of Economic Reforms in Nigeria, Selected Papers for the 2005 Annual Conference of NES, Pp. 331-367.

[32] Soludo, C. (2005), The Political Economy of Sustainable Democracy in Nigeria, 2005 Democracy Day Lecture, Federal Republic of Nigeria

[33] Todaro, M.P. and S.C. Smith (2003), Economic Development, New Delhi: Pearson Educational Ltd.

[34] UNDP (2009), Human Development Report 2009, CD ROM

[35] Uwatt, U.B. (2004), "Governance and Nigeria's Development Prospects" In: Garba, et al (eds), Leading Issues in Macroeconomic Management and Development, Ibadan: NES, Pp. 369-387

[36] Williamson, J. (1998), The Emergent Development Policy Consensus: Uncertain Paths to Sustainability after the Neo-liberal Revolution, Madison: Global Studies Programmes, University of Wisconsin.

[37] World Bank (1996), Nigeria, Poverty in the Midst of Plenty: the Challenges of Growth with Inclusion, Washington D.C.: Population and Human Resource Division.

[38] Yesufu, T.M.(1996), The Nigerian Economy: Growth Without Development, Benin City: The Benin Social Science Series for Africa 